Connie Pania Putri, Revitalisasi Konstitusional Dalam Penentuan Kandidat Presiden Melalui Pemilihan Demokratis, Halaman 35-49

\title{
REVITALISASI KONSTITUSIONAL DALAM PENENTUAN KANDIDAT PRESIDEN MELALUI PEMILIHAN DEMOKRATIS
}

\author{
Connie Pania Putri \\ Fakultas Hukum, Univesitas Kader Bangsa \\ Email: coniepania79@gmail.com
}

\begin{abstract}
The purpose of this research is to explain the constitutional revitalization in determining presidential candidates through democratic elections in internal parties. This research method is normative law or doctrinal legal research with a legal inventory approach. The results of the research can be explained that it is constitutionally determined that the state is based on the One Godhead. This study uses a normative approach method where the materials used are literature and library materials as well as laws. The conclusion in the research is constitutional revitalization as a process, means, act of reviving or reactivating in accordance with the Indonesian constitution with the philosophical foundation of Pancasila based on the one and only God for the realization of happiness for the Indonesian people. Constitutional revitalization in determining presidential candidates is related to the requirements for presidential candidates and democratic elections.
\end{abstract}

Keywords: constitutional; election; democratic

\begin{abstract}
Abstrak
Tujuan penelitian ini menjelaskan revitalisasi konstitusional dalam penentuan kandidat presiden melalui pemilihan demokratis di internal partai. Metode penelitian ini hukum normatif atau penelitian hukum doktrinal dengan pendekatan inventarisasi hukum. Hasil penelitian dapat dijelaskan bahwa secara konstitusional ditentukan bahwa negara berdasar atas Ketuhanan Yang Maha Esa. Penelitian ini menggunakan metode pendekatan normarif dimana bahan yang digunakan ialah literature dan bahan kepustakaan serta undang- undang. Kesimpulan dalam penelitian ialah revitalisasi konstitusional sebagai proses, cara, perbuatan menghidupkan atau menggiatkan kembali sesuai dengan konstitusi Indonesia dengan landasan filosofis Pancasila berbasiskan kepada Ketuhanan Yang Maha Esa demi wujudnya kebahagiaan bagi rakyat Indonesia. Revitalisasi konstitusional dalam penentuan kandidat presiden berkaitan dengan syarat kandidat presiden dan pemilihan demokratis.
\end{abstract}

Kata Kunci: konstitusional; pemilihan; demokratis

\section{PENDAHULUAN}

Sistem pemilihan umum
presiden dan wakil presiden di
Indonesia telah diatur dalam Undang-
Undang Dasar Negara Kesatuan
Republik Indonesia Tahun 1945

(selanjutnya UUD NKRI Tahun 1945). ${ }^{1}$ Pasal 6A Ayat (2) UUD NKRI Tahun 1945 menyebutkan bahwa "pasangan calon presiden dan wakil presiden diusulkan oleh partai politik atau

1 Ramlan Surbakti, Naskah Akademik Dan Draft RUU Kitab Hukum Pemilu: Usulan Masyarakat Sipil (Kemitraan bagi Pembaruan Tata Pemerintahan di Indonesia, 2015). 
Connie Pania Putri, Revitalisasi Konstitusional Dalam Penentuan Kandidat Presiden Melalui Pemilihan Demokratis, Halaman 35-49

gabungan partai politik peserta pemilihan umum sebelum pelaksanaan pemilihan umum". Berdasarkan ketentuan pasal ini, diketahui bahwa partai politik memiliki peran yang menentukan dalam sebuah sistem demokrasi modern dan juga merupakan pilar utama dalam pranata sistem politik. ${ }^{2}$ Berarti pula kandidat presiden dan wakil presiden hanya diusung dari partai atau gabungan partai politik.

Penentuan kandidat merupakan inti dari tatanan demokrasi (in the core of any democratic order) dan merupakan kegiatan mendasar dalam proses politik (a fundamental activity in the political process). ${ }^{3}$ Pemilihan presiden merupakan salah satu proses politik tersebut. Penentuan kandidat presiden senantiasa menjadi isu yang menarik disebabkan jumlah jabatan presiden hanya satu dalam suatu negara. ${ }^{4}$

UUD NKRI Tahun 1945 tidak menentukan mekanisme penentuan calon di tingkat partai politik. Untuk

2 Thomas Meyer, Peran Partai Politik Dalam Sebuah Sistem Demokrasi (Jakarta: FriedrichEbert-Stiftung (FES) Kantor Perwakilan Indonesia, 2012).

3 Miguel Pérez-Moneo, "Regulating Nominations in Political Parties: Candidates, Primaries and Law," 2020.

${ }^{4}$ Surbakti, Naskah Akademik Dan Draft RUU Kitab Hukum Pemilu: Usulan Masyarakat Sipil. pemilihan presiden dan wakil presiden sejak tahun 2004 telah diadakan pemilihan langsung oleh rakyat. 5 Pemilihan umum presiden dan wakil presiden secara langsung mempertegas sistem pemerintahan presidensil. ${ }^{6}$

Pemilihan presiden dan wakil presiden seharusnya tetap mengakomodir usulan bukan dari partai politik atau gabungan partai politik (independen). Meskipun ada pendapat pencalonan presiden independen memiliki lebih banyak kekurangan daripada keunggulan. Karena hanya diusung dari partai atau gabungan partai politik maka sistem pemilihan umum presiden dan wakil presidendi Indonesia belum mengakomodasi prinsip demokrasi secara penuh. ${ }^{7}$

Ketentuan UUD NKRI Tahun 1945 terkait pemilihan presiden secara teknis dijabarkan lebih lanjut dengan undang-undang, sedangkan dalam partai politik terdapat mekanisme dalam anggaran dasar dan anggaran

5 Sumono, "Pemilihan Presiden Dan Wakil Presiden Berdasarkan Sistem Presiden," 2014.

${ }^{6}$ Abu Tamrin, "Urgensi Pemilu Presiden Dan Wakil Presiden Secara Langsung Di Era Reformasi," Cita Hukum 1, no. 1 (2013): 194.

${ }^{7}$ Muh. Ikhsan Baso, "Sistem Pemilihan Umum Presiden Dan Wakil Presiden Indonesia Dengan Pencalonan Secara Independen (Perseorangan)," Jurnal Ilmu Hukum Legal Opinion 1, no. 5 (2013): 8. 
Connie Pania Putri, Revitalisasi Konstitusional Dalam Penentuan Kandidat Presiden Melalui Pemilihan Demokratis, Halaman 35-49

rumah tangga $(\mathrm{AD} / \mathrm{ART}) .^{8} \quad$ Dalam

kajian ini, penulis akan meninjau

sistem pemilihan umum presiden dan wakil presiden dalam undang-undang terdahulu, yaitu Undang-Undang Nomor 42 Tahun 2008 tentang Pemilu Presiden dan Wakil Presiden. ${ }^{9}$

Setiap partai politik yang dilengkapi dengan AD/ART, kelihatannya tidak menjamin terwujudnya penentuan kandidat presiden melalui pemilihan demokratis di internal partai. Sementara,rakyat terpaksa harus memilih calon presiden

8 Partai GOLKAR bersifat mandiri, terbuka, demokratis, moderat, solid, mengakar, responsif, majemuk, egaliter, serta berorientasi pada karya dan kekaryaan (AD ART Partai Golkar). Watak Partai GERINDRA adalah demokratis, merdeka, pantang menyerah, berpendirian teguh, percaya pada kekuatan sendiri dan kekuatan rakyat, terbuka dan taat hukum serta senantiasa memiliki watak sebagai pejuang yang berjuang untuk kepentingan rakyat (AD ART Partai Gerindra). Usaha sebagaimana dimaksud pada Ayat (1) dilaksanakan secara demokratis dan konstitusional (AD ART partai Persatuan Pembangunan). Tujuan umum didirikannya Partai ini adalah terwujudnya cita-cita nasional bangsa Indonesia sebagaimana dimaksud dalam Pembukaan UUD Tahun 1945 dan berkembangnya kehidupan demokrasi dengan menghormati kedaulatan rakyat dalam Negara Kesatuan Republik Indonesia berdasarkan prinsip-prinsip ajaran Islam (AD ART Partai Bulan Bintang). Watak Partai adalah gotong royong, demokratis, merdeka, pantang menyerah dan terbuka (AD ART PDI Perjuangan). Partai bersifat kebangsaan, demokratis dan terbuka (AD ART Partai PKB

${ }^{9}$ Surbakti, Naskah Akademik Dan Draft RUU Kitab Hukum Pemilu: Usulan Masyarakat Sipil. yang disodorkan partai politik. ${ }^{10}$ Menurut Slamet belum tentu proses seleksi calon presiden dan wakil presidendi internal partai politik memenuhi mekanisme yang demokratis sebagaimana yang dikehendaki masyarakat. Slamet mengingatkan bahwa partai politik cenderung bersifat oligarchy atau mempertahankan kekuasaannya pada sekelompok orang/golongan saja. Jadi, bukan tidak mungkin dalam proses seleksi calon presiden dan wakil presiden tersebut terdapat kepentingan kelompok yang dikedepankan. ${ }^{11}$

Pengusungan atau dukungan partai politik terhadap calon presiden dan wakil presiden yang sangat elitis dan berkonflik. Hal ini dapat dilihat dari beberapa kejadian internal politik yang rapuh karena kader tidak dilibatkan dalam mekanisme pengusungan calon presiden. Contohnya pada tingkat nasional Partai Persatuan Pembangunan (PPP) ketika Surya Dharma Ali selaku Ketua Umum PPP sepihak memberikan dukungan kepada Prabowo Subianto dan Hatta Rajasa, bahkan sebelum pemilihan

\footnotetext{
10 Zae, "Perlu Seleksi Internal Partai Yang Demokratis Soal Capres," n.d.

${ }^{11}$ Zae.
} 
Connie Pania Putri, Revitalisasi Konstitusional Dalam Penentuan Kandidat Presiden Melalui Pemilihan Demokratis, Halaman 35-49

legislatif terjadi. ${ }^{12}$ Begitu juga dengan Partai Golongan Karya (Partai Golkar), para kader seniornya menganggap Abu Rizal Bakrie terlalu egois dan terburuburu dalam menambatkan dukungan kepada Prabowo. Perpecahan di tubuh Partai Golkar dapat terlihat dari pembangkangan beberapa kadernya mendukung Joko Widodo dan Jusuf Kalla, seperti Luhut Pandjaitan, Nudirman Munir, dan lain-lain. ${ }^{13}$

Berdasarkan kondisi tersebut maka mekanisme penentuan calon presiden dan wakil presiden yang dilakukan oleh partai politik selama ini berlangsung secara tidak demokratis. ${ }^{14}$ Sehingga diperlukan kajian untuk menguji pernyataan bahwa Indonesia menjadi contoh dari sukses negara demokrasi. ${ }^{15}$

Realitas yang ada sangat penting untuk melakukan revitalisasi konstitusional dalam penentuan kandidat calon presiden dan wakil presiden melalui pemilihan demokratis di internal partai. Beberapa

\footnotetext{
12 Ican Ihsannuddin, "Suryadharma Tak Cabut Dukungannya Kepada Prabowo," n.d.

13 Fabian, "Tokoh Senior Golkar Dukung Jokowi," Laman Kompas Online, 2014.

${ }^{14}$ Fabian.

15 Farahdiba Rahma Bachtiar, "Pemilu Indonesia: Kiblat Negara Demokrasi Dari Berbagai Refresentasi," Jurnal Profetik 3, no. 1 (2014): 25.
}

pertimbangan secara kronologis revitalisasi konstitusional menjadi sangat penting karena: 1. Negara Indonesia diselenggarakan secara konstitusional. 2. Presiden adalah pemegang kekuasaan pemerintahan negara. 3. Calon presiden dan wakil presiden diusulkan oleh partai politik dan gabungan partai politik. 4. Pemilihan presiden dan wakil presiden dilaksanakan melalui pemilihan umum (pemilu). 5. Pemilu dilaksanakan secara demokratis.

Memperhatikan pertimbangan di atas dapat diketahui bahwa pemilihan presiden dan wakil presiden yang demokratis harus dimulai di internal partai politik. Oleh sebab itu, fokus utama penelitian ini terkait revitalisasi konstitusional dengan mengedepankan tinjauan filosofis dan normatif terhadap teks UUD NKRI Tahun 1945 dilengkapi dengan aturan undangundang. Untuk kajian di internal partai dilakukan tinjauan dengan menganalisisAD/ART partai politik. Alasan dan dasar pemikiran pembahasan revitalisasi konstitusi tidak terlepas daripentingnya posisi konstitusi (UUD NKRI Tahun 1945) dalam suatu negara. UUD NKRI Tahun 1945 ditempatkan pada kedudukan 
Connie Pania Putri, Revitalisasi Konstitusional Dalam Penentuan Kandidat Presiden Melalui Pemilihan Demokratis, Halaman 35-49

yang tinggi (supreme). Ada semacam jaminan bahwa konstitusi itu akan diperhatikan dan ditaati. ${ }^{16}$

Penelitian tentang revitalisasi konstitusional dalam penentuan kandidat presiden melalui pemilihan demokratis di internal partai belum pernah disentuh oleh penulis lain. Beberapa terdahulu diantaranya Sri Handayani Retna Wardani hanya meneliti tentang tolok ukur demokrasi Pancasila dalam membentuk UndangUndang Pemilu Legislatif. Hasil penelitiannya menjelaskan pembentukan undang-undang bidang politik tidak menggunakan model dan tidak sesuai dengan konsep negarahukum sebagaimana diamanatkan dalam konstitusi (UUD NRI Tahun1945) dan tidak sesuai denganideologi Pancasila sebagai landasan filosofisnya. ${ }^{17}$

Wimmy Halim pernah meneliti tentang demokrasi deliberatif indonesia: konsep partisipasi masyarakat dalam membentuk demokrasi dan hukum yang responsif.

16 Ni'matul Huda, UUD 1945 Dan Gagasan Amandemen Ulang (Jakarta: Rajawali Pers, 2008).

${ }^{17}$ Sri Handayani Retna Wardani, “Tolok Ukur Demokrasi Pancasila Dalam Membentuk Undang-Undang Pemilu Legislatif," Jurnal Kajian Hukum 1, no. 1 (2016): 92.
Dalam penelitiannya dijelaskan kekuatan konstituen dapat membentuk hukum dalam sistem demokrasi deliberatif dan direct popular checks atau pemeriksaan langsung oleh masyarakat. Artinya,masyarakat ditempatkan sebagai sebuah pilar yang dapat mengawasi jalannya pemerintahan. Pada hakikatnya,sistem ini merupakan sarana-sarana ultrademokrasi yang merupakan perluasan proses legislatif di luar majelis yang dibentuk oleh masyarakat. Hal ini menjadi penting dalam rangka peningkatan kualitas demokrasi Indonesia. ${ }^{18}$

Lambang Trijono meneliti tentang reaktualisasi politik demokrasi: politik agensi dan revitalisasi kelembagaan demokrasi. Dalam penelitiannya menggarisbawahi wacana pembentukan subyek politik baru melalui pengembangan model politik agonistik yang diasumsikan dapat lebih merepresentasikan kepentingan publik dan mampu mengaktivasi lembaga-lembaga politik

\footnotetext{
18 Wimmy Halim, "Demokrasi Deliberatif Indonesia: Konsep Partisipasi Masyarakat Dalam Membentuk Demokrasi Dan Hukum Yang Responsif," Jurnal Masyarakat Indonesia 42, no. 1 (2016): 19.
} 
Connie Pania Putri, Revitalisasi Konstitusional Dalam Penentuan Kandidat Presiden Melalui Pemilihan Demokratis, Halaman 35-49

untuk kembali menjalankan fungsinya. ${ }^{19}$

Abdul Latif pernah menulis tentang pemilihan presiden (pilpres) dalam perspektif koalisi multipartai. Dalam tulisannya dijelaskan bahwa perlu persepsi yang sama tentang sistem pemerintahan. Sistem campuran harus jelas bagian-bagian yang menggunakan sistem parlementer dan bagian yang masih menggunakan sistem presidensil. Ketidakjelasan sistem campuran akan menimbulkan kekaburan tentang hak dan kewajiban Presiden. Kebenaran yang didasarkan suara terbanyak tidak selalu menggambarkan kualitas yang didukung oleh kebenaran teoritik. ${ }^{20}$

Bila ditelaah penelitian terdahulu tersebut jelas tidak ada kaitannya dengan revitalisasi konstitusional dalam penentuan kandidat presiden melalui pemilihan demokratis di internal partai. Adapun permasalahan yang dibahas dalam penelitian ini terkait dengan konsepsi revitalisasi konstitusional dalam

19 Lambang Trijono, "Reaktualisasi Politik Demokrasi: Politik Agensi Dan Revitalisasi Kelembagaan Demokrasi," Jurnal Ilmu Sosial Dan Ilmu Politik 15, no. 2 (2011): 93.

20 Abdul Latif, "Pilpres Dalam Perspektif Koalisi Multiparta," Jurnal Konstitusi 6, no. 3 (2009): 49. penentuan kandidat presiden dan penentuan kandidat presiden melalui pemilihan demokratis di internal partai. Hasil yang diharapkan dari penelitian ini untuk menjelaskan revitalisasi konstitusional dalam penentuan kandidat presiden melalui pemilihan demokratis di internal partai. Selain itu, penelitian ini diharapkan dapat dijadikan pengembangan ilmu pengetahuan khususnya hukum tata negara.

Dari latar belakang di atas, maka penulis membahas tentang revitalisasi konstitusional dalam penentuan kandidat presiden melalui pemilihan demokratis.

Penelitian ini adalah penelitian hukum normatif atau penelitian hukum doktrinal dengan pendekatan inventarisasi hukum, yaitu mengumpulkan norma-norma yang sudah diidentifikasi sebagai norma hukum. Sebagai penelitian hukum normatif maka sumber data yang dipergunakan berupa data sekunder, terdiri dari bahan hukum primer, sekunder dan tersier. Analisis data penelitian secara secara kualitatif, yakni membandingkan atau menerapkan peraturan perundangundangan yang berlaku, pendapat para 
Connie Pania Putri, Revitalisasi Konstitusional Dalam Penentuan Kandidat Presiden Melalui Pemilihan Demokratis, Halaman 35-49

sarjana (doktrin) serta teori-teori hukum lainnya. Kesimpulan penelitian secara deduktif, yakni penarikan kesimpulan diawali dari yang bersifat umum kepada yang bersifat khusus.

\section{PEMBAHASAN}

\section{A. Revitalisasi}

Konstitusional

Tentang Syarat Calon Presiden dan Wakil Presiden

Berdasarkan Pasal 6 Ayat (1) dan Pasal 6 A Ayat (2) UUD NKRI Tahun 1945, calon presiden dan calon wakil presiden harus memenuhi syarat sebagai berikut:

a. Warga negara Indonesia sejak kelahirannya dan tidak pernah menerima kewarganegaraan lain karena kehendaknya sendiri.

b. Tidak pernah mengkhianati negara.

c. Mampu secara rohani dan jasmani untuk melaksanakan tugas dan kewajiban sebagai presiden dan wakil presiden.

d. Dipilih dalam satu pasangan secara langsung oleh rakyat.

e. Diusulkan oleh partai politik atau gabungan partai politik peserta pemilihan umum sebelum pelaksanaan pemilihan umum.

Ketentuan UUD NKRI Tahun 1945 menyebutkan bahwa calon presiden dan calon wakil presiden harus mampu secara rohani dan jasmani untuk melaksanakan tugas dan kewajibannya. Persoalannya, siapa yang dikategorikan mampu tersebut dengan menggunakan prinsip revitalisasi konstitusional maka mutlak memaknai secara intensif. Ketentuan dalam UUD NKRI secara komprehensif, bukan sepotongsepotong. Karena ketentuan UUD NKRITahun 1945 adalah penjabaran dari Pancasila yang dijiwai dengan prinsip Ketuhanan Yang Maha Esa. Oleh sebab itu, intensitas pemaknaan kata mampu mutlak dioptimalkan sesuai dengan ketentuan Tuhan Yang Maha Esa.

Dalam konteks ini, Tuhan Yang Maha Esa telah memberikan potensi kepada segenap Warga Negara Indonesia untuk menjadi pemimpin sesuai dengan amanah konstitusi. Walaupun demikian, dalam perkembangannya tidak setiap orang mampu mengembangkan potensi kepemimpinan, sehingga hanya orangorang tertentu saja yang menjadi 
Connie Pania Putri, Revitalisasi Konstitusional Dalam Penentuan Kandidat Presiden Melalui Pemilihan Demokratis, Halaman 35-49

kandidat presiden dan wakil presiden yang dicalonkan oleh partai politik atau gabungan partai politik.

$$
\text { Upaya merintis intensitas }
$$

revitalisasi konstitusional penting artinya untuk memahami spirit yang mengemuka ketika dilakukan proses Amandemen UUD NKRI Tahun 1945. Usulanusulan yang muncul dalam Amandemen UUD NKRI Tahun 1945 sebagai berikut. a. Syarat-syarat keadaan diri secara lengkap itu diatur dengan undangundang, agar bisa lebih teliti, lebih luwes, lengkap, utuh, dan terpadu. ${ }^{21}$ b. Berkaitan dengan mental, didefinisikan oleh kalangan medis berupa rangeyang luas. Menurut kalangan agamawan, bicara tentang mental tentang sesuatu yang tidak jelas batasannya sehingga tidak mungkin dijabarkan terlalu rinci dalam UUD NKRI Tahun 1945. Hal ini diatur lebih lanjut dengan undangundang, karena di tingkat undangundang terdapat bagian penjelasan yang dapat uraikan lebih terperinci. Intinya bahwa memang seorang calon presiden dan calon wakil presiden itu harus ada persyaratan

21 Mahkamah Konstitusi, Naskah Komprehensif Perubahan Undang-Undang Dasar Negara Republik Indonesia Tahun 1945 Buku IV Kekuasaan Pemerintahan Negara (Jakarta: Sekretariat Jenderal dan Kepaniteraan MK, 2010). jelas. Tapi persyaratan yang seperti apa, itu harus dengan persepsi yang sama dan harus terperinci dijelaskan. Misalkan, pengertian cacat, fisik, psikis, dan lain sebagainya. ${ }^{22} \mathrm{c}$. Tentang persyaratan yang akan dipilih itu memang orang yang sempurna, sehat lahir batin, mental, dan fisiknya. Meskipun ada di antara kepala negara yang pernah tidak sempurna. Tetapi, dalam 250-an juta rakyat Indonesia apa tidak ada yang sempurna. Apalagi nantinya akan dipilih oleh rakyat secara langsung. Oleh karena itu, diharapkan agar syarat sehat mental dan fisik itu harus dicantumkan pada konstitusi. Nantinya, secara rinci bagaimana keterangan sehat fisik, mental dicantumkan pada undang-undang. ${ }^{23} \mathrm{~d}$. Syarat pengajuan yang tidak debatable, karena itu menjadi persyaratan yang mendasar termasuk jasmani dan rohani. Jasmani dan rohani pun menjadi syarat untuk semua, calon pegawai negeri atau calon apapun biasanya diminta syarat dengan surat keterangan menjadi suatu hal yang umum. Tapi, kalau untuk mengatur supaya tidak diperdebatkan, terkait dengan klausul Ayat (2) itu sebenarnya sudah bisa

\footnotetext{
${ }^{22}$ Konstitusi.

${ }^{23}$ Konstitusi.
} 
Connie Pania Putri, Revitalisasi Konstitusional Dalam Penentuan Kandidat Presiden Melalui Pemilihan Demokratis, Halaman 35-49

menyelesaikan masalah. Undangundang mengatur bagaimana sehat jasmani dan rohani calon, sehingga menjadi persyaratan mendasar. ${ }^{24}$

Usulan-usulan yang mengilhami lahirnya ketentuan dalam UUD NKRI Tahun 1945 yang menentukan persyaratan untuk menjadi calon presiden dan wakil presiden sebagaimana diatur pada Pasal 6 Ayat (2) UUD NKRI Tahun 1945. Penyelenggaraan pemilihan umum yang demokratis, dibentuklah pengaturan berupa undang-undang maupun turunnyayang menjelaskan lebih rinci persyaratan maupun teknis pelaksanaan pemilu. Dalam hal pemilu presiden dan wakil presiden, terdahulu dibentuk dengan UndangUndangNomor 23 Tahun 2003 yang kemudian diubah dengan UndangUndang Republik Indonesia Nomor 42 Tahun 2008 tentang PemilihanUmum Presiden dan Wakil Presiden. ${ }^{25}$

Pasal 6 Undang-Undang Nomor 23 Tahun 2003 tentang Pemilihan Umum Presiden dan Wakil Presiden

\footnotetext{
${ }^{24}$ Konstitusi.

${ }^{25}$ Ahmad Farhan Subhi, "Pengusulan Pasangan Calon Presiden Dan Wakil Presiden Sebagai Peserta Pemilu Menurut Undang-Undang Pilpres," Jurnal Cita Hukum Fakultas Syariah Dan Hukum UIN Syarif Hidayatullah II, no. 2 (2015): 341 .
}

menentukan syarat bagi calon presiden dan calon wakil presiden sebagai berikut. a. Bertaqwa kepada Tuhan Yang Maha Esa. b. Warga negara Indonesia sejak kelahirannya dan tidak pernah menerima kewarganegaraan lain karena kehendaknya sendiri. c. Tidak pernah mengkhianati negara. d. Mampu secara rohani dan jasmani untuk melaksanakan tugas dan kewajiban sebagai presiden dan wakil presiden. e. Bertempat tinggal dalam wilayah Negara Kesatuan Republik Indonesia. f. Telah melaporkan kekayaannya kepada instansi yang berwenang memeriksa laporan kekayaan penyelenggara negara. g. Tidak sedang memiliki tanggungan utang secara perseorangan dan/atau secara badan hukum yang menjadi tanggung jawabnya yang merugikan keuangan negara. h. Tidak sedang dinyatakan pailit berdasarkan putusan pengadilan. i. Tidak sedang dicabut hak pilihnya berdasarkan putusan pengadilan yang telah mempunyai kekuatan hukum tetap. j. Tidak pernah melakukan perbuatan tercela. $\mathrm{k}$. Terdaftar sebagai pemilih. 1. Memiliki Nomor Pokok Wajib Pajak (NPWP) dan telah melaksanakan kewajiban pajak selama 5 (lima) tahun terakhir 
Connie Pania Putri, Revitalisasi Konstitusional Dalam Penentuan Kandidat Presiden Melalui Pemilihan Demokratis, Halaman 35-49

yang dibuktikan dengan Surat Pemberitahuan Tahunan Pajak Penghasilan Wajib Pajak Orang Pribadi. m. Memiliki daftar riwayat hidup. n. Belum pernah menjabat sebagai presiden dan wakil presiden selama dua kali masa jabatan dalam jabatan yang sama. o. Setia kepada Pancasila sebagai dasar negara, UUD Tahun 1945, dan cita-cita Proklamasi 17 Agustus 1945. p. Tidak pernah dihukum penjara karena melakukan tindak pidana makar berdasarkan putusan pengadilan yang telah mempunyai kekuatan hukum tetap. q. Berusia sekurang-kurangnya 35 (tiga puluh lima) tahun. r. Berpendidikan serendah-rendahnya SLTA atau yang sederajat. s. Bukan bekas anggota organisasi terlarang Partai Komunis Indonesia, termasuk organisasi massanya, atau bukan orang yang terlibat langsung dalam G 30 S/PKI. t. Tidak pernah dijatuhi pidana penjara berdasarkan putusan pengadilan yang mempunyai kekuatan hukum tetap karena melakukan tindak pidana yang diancam dengan pidana penjara lima tahun atau lebih.

Konsep revitalisasi konstitusional berupa syarat bertaqwa kepada Tuhan Yang Maha Esa. Kesalehan seorang pemimpin negara diukur pada seberapa baik akhlaknya, seberapa kuat komitmen dan kemampuanuntuk mencapai tujuan kepemimpinan untuk menegakkan keadilan dan kemakmuran bagi segenap rakyat. $^{26}$ Ketentuan Tuhan yang menyebut tentang syarat takwa sebagai berikut. a. And believe in what I reveal, confirming the revelation which is with you,and be not the first to reject Faith therein, nor sell My Signs for a smallprice; and fear Me, and Me alone (Q.S. Baqara (2) : 41). b. It is not righteousness that ye turn your faces towards east or west; butit is righteousness- to believe in Allah and the last day, and the angels, andthe book, and the messengers; to spend of your substance, out of love for Him,for your kin, for orphans, for the needy, for the wayfarer, for those who ask, and for the ransom of slaves; to be steadfast in prayer, and practice regularcharity; to fulfil the contracts which ye have made; and to be firm and patient,in pain [or suffering] and adversity, and throughout all periods of panic. Suchare the people of truth, the Allahfearing (Q.S. Baqara (2): 177). c. The prohibited month for the prohibited month,- and so for all thingsprohibited,- there is the law of equality. If then any one transgresses theprohibition against you, transgress ye likewise against him. But fear Allah, andknow that Allah is with those who restrain themselves(Q.S. Baqara (2): 194). d. O ye who believe! Fear Allah, and give up what remains of your demand forusury, if ye are indeed believers (Q.S. Baqara (2): 278).

Bila ditinjau cita negara Hukum Indonesia yang berdasarkan Pancasila, ide kenegaraan tidak dapat dilepaskan

\footnotetext{
${ }^{26}$ Masdar Farid Mas'udi, Syarah UUD 1945 Perspektif Islam (PT Pustaka Alvabet, 2013).
} 
Connie Pania Putri, Revitalisasi Konstitusional Dalam Penentuan Kandidat Presiden Melalui Pemilihan Demokratis, Halaman 35-49

dari nilai Ketuhanan Yang Maha Esa Sila Pertama dari Pancasila. Oleh karena itu, negara Indonesia menjunjung tinggi nilai-nilai ke-Maha Esaan dan ke-Maha Kuasaan Tuhan. Artinya, diakuinya prinsip supremasi hukum tidak mengabaikan keyakinan mengenai ke-Maha Kuasa-an Tuhan Yang Maha Esa yang diyakini sebagai Sila Pertama dari Pancasila. Pengakuan segenap bangsa Indonesia mengenai kekuasaan tertinggi yang terdapat dalam hukum tidak boleh bertentangan dengan keyakinan segenap warga bangsa mengenai prinsip dan nilai-nilai ke-Maha-Kuasa-an Tuhan Yang Maha Esa dan di pihak lain pengakuan akan prinsip supremasi hukum itu juga merupakan pengejawantahan atau ekspresi kesadaran rasional kenegaraan atas keyakinan pada Tuhan Yang Maha Esa yang menyebabkan setiap manusia Indonesia hanya memutlakkan Yang Esa dan menisbikan kehidupan antar sesama warga yang bersifat egaliter dan menjamin persamaan dan penghormatan atas kemajemukan dalam kehidupan bersama dalam wadah negara Pancasila. ${ }^{27}$

\footnotetext{
${ }^{27}$ Jimly Asshiddiqie, "Gagasan Negara Hukum Indonesia," n.d.
}

Menyertakan moral Ketuhanan sebagai dasar negara memberikan dimensi transcendental pada kehidupan politik serta mempertemukan hubungan simbiosis antara konsepsi daulat Tuhan dan daulat rakyat. Pancasila dalam kehidupan kebangsaan dan kenegaraan terangkat dari tingkat sekuler ke tingkat moral atau sakral. Rekonsiliasi antara tendensi kearah sekularisasi dan sakralisasi dengan wawasan Ketuhanan diharapkan dapat memperkuat etos kerja, karena kualitas kerja ditransendensikan dari batasan hasil kerja materialnya. Oleh karena itu, teologi kerja yang transendental memberi nilai tambah spiritual maka memperkuat motivasi di satu pihak dan di pihak lain memperbesar inspirasi dan aspirasi warga negara. Wawasan teosentris menuntut untuk pandai menjangkarkan kepentingan (interest) kepada nilai (value) dalam politik. ${ }^{28}$ Pancasila mengakui tentang Ketuhanan. ${ }^{29}$

Tuhan Yang Maha Esa menetapkan doktrin akan keEsaan dan Kekuasaan-Nya (the unity and

\footnotetext{
28 Pimpinan MPR dan Tim Kerja Sosialisasi MPR Periode 2009-2014, Empat Pilar Kehidupan Berbangsa Dan Bernegara (Jakarta: Sekretariat Jenderal MPR RI, 2013). ${ }^{29}$ Budiyono, "Hubungan Negara Dan Agama Dalam Negara Pancasila," Fiat Justisia Jurnal Ilmu Hukum 8, no. 3 (2014): 410.
} 
Connie Pania Putri, Revitalisasi Konstitusional Dalam Penentuan Kandidat Presiden Melalui Pemilihan Demokratis, Halaman 35-49

souverenity of God). Ajaran ini menjangkau seluruh aspek kehidupan manusia, tidak terkecuali aspek politik ketatanegaraan serta pemerintahan. ${ }^{30} \mathrm{Di}$ antara ayat hukum Tuhan yang berkenaan dengan kepemimpinan adalah Surat the Women verse 58-59: Indeed, Allah commands you to render trusts to whom they are due and when you judge between people to judge with justice. Excellent is that which Allah instructs you. Indeed, Allah is ever hearing and seeing (verse: 58); O you who have believed, obey Allah and obey the messenger and those in authority among you. And if you disagree over anything, refer it to Allah and the Messenger, if you should believe in Allah and the last day. That is the best [way] and best in result (verse: 59).

Ketentuan Tuhan yang menyebutkan: let not believers take disbelievers as allies rather than believers. And whoever [of you] does that has nothing with Allah, except when taking precaution against them in prudence. And Allah warns you of Himself, and to Allah is the [final] destination (al-Kitab - the Family of Imran: 28). Sejalan dengan ketentuan Tuhan sebelumnya, utusan Tuhan (the messenger) yang menyebutkan bahwa: each one of you is a leader and each of you is responsible for what you lead. Pada kesempatan lain disebutkan

${ }^{30}$ Trianto dan Titik Triwulan Tutik, Falsafah Negara Dan Pendidikan Kewarganeraan (Jakarta: Prestasi Pustaka Publisher, 2007). bahwa the Scientists heirs of the Prophets.

Berdasarkan ketentuan Tuhan dan utusan-Nya dalam hubungandengan penentuan kandidat presiden diketahui bahwa kandidat presiden itu harus taat kepada Tuhan dan utusan-Nya, amanah, shiddiq, tabligh, dan fathanah. Berdasarkan intensitas hukum mutlak dipahami bahwa hukum Tuhan tidak boleh diabaikan oleh manusia dengan alasan apapun. Larangan terhadap pengabaian itu dikarenakan kegunaan hukum itu adalah untuk kebaikan manusia itu sendiri. Ketika pengabaian hukum Tuhan terjadi maka tidak akan ada wujud keadilan, kepastian, dan kemanfaatan hukum dalam artian yang sesungguhnya. Begitu juga tidak akan muncul kesadaran dan kepatuhan hukum di tengah-tengah masyarakat. Peringatan Tuhan sangat jelas, diantaranya menyebutkan:

Then seest thou such a one as takes as his god his own vain desire? Allahhas, knowing [him as such], left him astray, and sealed his hearing and hisheart [and understanding], and put a cover on his sight. Who, then, will guidehim after Allah [has withdrawn guidance]? Will ye not then receive admonition?(Q.S. Jatsiya (45): 23).O ye people! adore your guardian-lord, who created you and those who camebefore you, that ye may have the 
Connie Pania Putri, Revitalisasi Konstitusional Dalam Penentuan Kandidat Presiden Melalui Pemilihan Demokratis, Halaman 35-49

chance to learn righteousness(Q.S. Baqara (2): 21). Who has made the earth your couch, and the heavens your canopy; and sentdown rain from the heavens; and brought forth therewith Fruits for yoursustenance; then set not up rivals unto Allah when ye know [the truth]. (Q.S. Baqara (2): 22).

Tantangan untuk lahirnya kesadaran dan kepatuhan kepada hukum Tuhan datang dari manusia yang suka membangkang, manusia yang memperturutkan hawa nafsu, manusia yang bersangkutan membutuhkan hidayah Tuhan dalam kehidupannya.

\section{KESIMPULAN}

Konsepsi revitalisasi

konstitusional sebagai proses, cara, perbuatan menghidupkan atau menggiatkan kembali sesuai dengan konstitusi Indonesia dengan landasan filosofis Pancasila berbasiskan kepada Ketuhanan Yang Maha Esa demi wujudnya kebahagiaan bagi rakyat Indonesia. Revitalisasi konstitusional dalam penentuan kandidat presiden berkaitan dengan syarat kandidat presiden dan pemilihan demokratis. Syarat utama kandidat presiden adalah bertaqwa kepada Tuhan Yang Maha Esa, sedangkan pelaksanaan pemilihan demokratis mesti dengan prinsip amanah dan prosedur yang memberi ruang partisipasi seluruh rakyat dilandasi dengan prinsip Ketuhananan Yang Maha Esa.

\section{DAFTAR PUSTAKA}

2009-2014, Pimpinan MPR dan Tim Kerja Sosialisasi MPR Periode. Empat Pilar Kehidupan Berbangsa Dan Bernegara. Jakarta: Sekretariat Jenderal MPR RI, 2013.

Asshiddiqie, Jimly. "Gagasan Negara

Hukum Indonesia," n.d.

Bachtiar, Farahdiba Rahma. "Pemilu Indonesia: Kiblat Negara Demokrasi Dari Berbagai Refresentasi." Jurnal Profetik 3, no. 1 (2014): 25.

Baso, Muh. Ikhsan. "Sistem Pemilihan

Umum Presiden Dan Wakil

Presiden Indonesia Dengan

Pencalonan Secara Independen (Perseorangan)." Jurnal Ilmu

Hukum Legal Opinion 1, no. 5 (2013): 8 .

Budiyono. "Hubungan Negara Dan Agama Dalam Negara Pancasila." Fiat Justisia Jurnal Ilmu Hukum 8, no. 3 (2014): 410.

Fabian. "Tokoh Senior Golkar Dukung 
Connie Pania Putri, Revitalisasi Konstitusional Dalam Penentuan Kandidat Presiden Melalui Pemilihan Demokratis, Halaman 35-49

Jokowi.” Laman Kompas Online, 2014.

Halim, Wimmy. "Demokrasi Deliberatif Indonesia: Konsep Partisipasi Masyarakat Dalam Membentuk Demokrasi Dan Hukum Yang Responsif.” Jurnal Masyarakat Indonesia 42, no. 1 (2016): 19.

Huda, Ni'matul. UUD 1945 Dan Gagasan Amandemen Ulang. Jakarta: Rajawali Pers, 2008.

Ihsannuddin, Ican. "Suryadharma Tak Cabut Dukungannya Kepada Prabowo," n.d.

Konstitusi, Mahkamah. Naskah Komprehensif Perubahan Undang-Undang Dasar Negara Republik Indonesia Tahun 1945 Buku IV Kekuasaan Pemerintahan Negara. Jakarta: Sekretariat Jenderal dan Kepaniteraan MK, 2010.

Latif, Abdul. "Pilpres Dalam Perspektif Koalisi Multiparta.” Jurnal Konstitusi 6, no. 3 (2009): 49.

Mas'udi, Masdar Farid. Syarah UUD 1945 Perspektif Islam. PT Pustaka Alvabet, 2013.

Meyer, Thomas. Peran Partai Politik Dalam Sebuah Sistem Demokrasi. Jakarta: Friedrich-Ebert-Stiftung
(FES) Kantor Perwakilan Indonesia, 2012

Pérez-Moneo, Miguel. "Regulating Nominations in Political Parties: Candidates, Primaries and Law," 2020 .

Subhi, Ahmad Farhan. "Pengusulan Pasangan Calon Presiden Dan Wakil Presiden Sebagai Peserta Pemilu Menurut Undang-Undang Pilpres." Jurnal Cita Hukum Fakultas Syariah Dan Hukum UIN Syarif Hidayatullah II, no. 2 (2015): 341

Sumono. "Pemilihan Presiden Dan Wakil Presiden Berdasarkan Sistem Presiden," 2014.

Surbakti, Ramlan. Naskah Akademik Dan Draft RUU Kitab Hukum Pemilu: Usulan Masyarakat Sipil. Kemitraan bagi Pembaruan Tata Pemerintahan di Indonesia, 2015.

Tamrin, Abu. "Urgensi Pemilu Presiden Dan Wakil Presiden Secara Langsung Di Era Reformasi." Cita Hukum 1, no. 1 (2013): 194.

Trijono, Lambang. "Reaktualisasi Politik Demokrasi: Politik Agensi Dan Revitalisasi Kelembagaan Demokrasi." Jurnal Ilmu Sosial Dan Ilmu Politik 15, no. 2 (2011): 
Connie Pania Putri, Revitalisasi Konstitusional Dalam Penentuan Kandidat Presiden Melalui Pemilihan Demokratis, Halaman 35-49

93.

Tutik, Trianto dan Titik Triwulan.

Falsafah Negara Dan Pendidikan

Kewarganeraan. Jakarta: Prestasi

Pustaka Publisher, 2007.

Wardani, Sri Handayani Retna. “Tolok

Ukur Demokrasi Pancasila Dalam

Membentuk Undang-Undang

Pemilu Legislatif." Jurnal Kajian

Hukum 1, no. 1 (2016): 92.

Zae. "Perlu Seleksi Internal Partai

Yang Demokratis Soal Capres,"

n.d. 